\title{
KUALITAS KETERAMPILAN PROSES SAINS SISWA YANG TERBIASA TEACHER-CENTERED LEARNING MELALUI PROCESS ORIENTED GUIDED INQUIRY LEARNING
}

\author{
R. Arizal Firmansyah ${ }^{1}$ dan Umi Khumaidah ${ }^{2}$ \\ ${ }^{1}$ Pendidikan Kimia, Fakultas Sains dan Teknologi, UIN Walisongo, Jl. Prof. Dr. \\ Hamka Km. 2 Ngaliyan, Kota Semarang, 50185, Indonesia \\ ${ }^{2}$ Japanese Mathematics Center Jl. Ngesrep Timur V No.8 Tembalang, \\ Kota Semarang, 50275, Indonesia \\ E-mail: r.arizalfirmansyah@walisongo.ac.id
}

\begin{abstract}
ABSTRAK
Banyak peneliti yang telah menyarankan bahwa siswa harus dilibatkan dalam proses penemuan konsep kimia melalui Keterampilan Proses Sains (KPS) dan pembelajaran inkuiri. Namun, menjadi tantangan tersendiri jika KPS dan pembelajaran inkuiri diterapkan pada siswa yang telah terbiasa pada pembelajaran berpusat pada guru, belum pernah sama sekali mengenal KPS dan pembelajaran inkuiri, salah satunya adalah siswa kelas XI IPA MAN 1 Pati. Oleh karena itu melalui penelitian ini bagaimana kualitas KPS melalui Process Oriented Guided Inquiry Learning (POG/L) pada materi asam basa dan larutan penyangga pada siswa tersebut akan diuraikan. Kualitas KPS tersebut diperoleh melalui mixed methods dengan desain embedded concurrent. Data penelitian diperoleh melalui teknik observasi, wawancara, dan catatan lapangan. Berdasarkan data hasil penelitian yang diperoleh secara keseluruhan menunjukkan bahwa siswa kelas XI IPA MAN 1 Pati mempunyai KPS yang cukup baik dengan persentase rata-rata 67,34\%. Setiap aspek KPS diantaranya pada aspek mengamati 85,00\% (Baik); aspek mengklasifikasi 77,12\% (Baik); aspek menggunakan alat dan bahan 80,62\% (Baik); aspek mengukur 55,00\% (Kurang); aspek menginterpretasi data 66,00\% (Cukup); aspek mengkomunikasikan 58,78\% (Cukup); dan aspek menyimpulkan 47,62\% (Kurang). Kemampuan siswa pada aspek mengukur dan menyimpulkan belum memuaskan pada kegiatan praktikum asam basa dan larutan penyangga yang telah dilaksanakan.
\end{abstract}

Kata kunci: keterampilan proses sains, pendekatan pembelajaran, pembelajaran kimia

\begin{abstract}
There are many researchers who suggested that students must be engaged in the invention of their understanding to the chemistry concepts by Science Process Skills (SPS) and inquiry learning. However, it will be challenge if SPS and inquiry learning are applied to the students who have been accustomed learning in the teacher centered classroom and they do not recognize the SPS and inquiry learning yet. This research was carried out at MAN 1 Pati to students in class of XI-IPA who studied by teacher center learning method. In this paper, we will discuss the quality of SPS through Process Oriented Guided Inquiry Learning (POGIL) which has been implemented in that class, the students' understanding as the mastery aspect of the concepts and its relationship to the SPS. We proposed that the quality of SPS will be obtained by the mixed methods with embedded concurrent design. Also, we collected the data by observation, interview, and field notes. As the result, the data shown that the students in the class of XI IPA at MAN 1 Pati had a good enough of SPS with average percentage 67.34. Moreover, their average and quality of observing was 85 (good), classifying was 77.12 (very good), handling laboratory equipment and chemicals was 55 (less), data interpretation was 66 (enough), and making a conclusion was 47.62 (less). In other words, the students ability to measure and make a conclusion in this research by doing experiment of acid, base, and buffer concepts are not satisfied yet.
\end{abstract}

Keywords: Science process skills, approach to learning, the learning of chemistry DOI: https://doi.org/10.15575/jtk.v2i2.1878 


\section{PENDAHULUAN}

Keefektifan pembelajaran sains secara umum (termasuk kimia di dalamnya) tergantung pada pendekatan yang digunakan guru selama proses pembelajaran (Tuckwell, 1869; Coulson, 1972; Das, 1985; Paixão dan Cachapuz, 2000). Diantara pendekatan pembelajaran yang direkomendasikan adalah kerja laboratorium atau praktikum (Reid dan Shah, 2007; Hofstein, 2004; Tomasevic dan Trivic, 2014). Keterampilan yang diajarkan dalam praktikum adalah Keterampilan Proses Sains (KPS) yang merupakan seperangkat keterampilan intelektual non prosedural yang digunakan untuk memahami alam. Seperangkat intelektual ini merefleksikan perilaku saintis dan dikatakan sebagai way to link previous and current knowledge (Ash, 2000; Padilla, 1990). Pada awalnya peran KPS dalam pembelajaran tidak begitu diperhatikan. Bahkan, aktivitas laboratorium dalam dunia pendidikan hanya bertujuan sebatas mengkonfirmasi informasi dalam text book atau penjelasan guru. Namun seiring perjalanan waktu, KPS yang merupakan bagian dari kerja laboratorium lebih diperhatikan. Bahkan KPS yang ditambahkan ke dalamnya metode inkuiri mampu membantu siswa berpikir pemecahan masalah. Tentunya banyak aspek pendukungnya diantaranya adalah buku petunjuk praktikum yang berorientasi pada inkuiri, lingkungan sosial guru dan siswa yang semakin tidak formal memungkinkan siswa membangun konsepnya, pemahaman kepada siswa tentang pentingnya pola berpikir pemecahan masalah, peran teknologi yang dapat memberikan waktu lebih banyak kepada siswa untuk membangun konsepnya sendiri (Hofstein dan Lunetta, 1982; Hofstein dan Lunetta, 2003).

Pembelajaran sains khususnya kimia di Indonesia, masih mengedepankan penguasaan konsep-konsep kimia sematamata melalui memori bukan KPS. Beberapa penelitian telah melaporkan bahwa KPS kimia di Indonesia tergolong rendah (Wardani et.al., 2009; Rahmawati et.al., 2014; Afiyanti, et.al.,
2014; Avianti dan Yonata, 2015; Hardiyanti, et.al., 2017; Fitriyani et.al., 2017). Salah satu contoh nyata yang terjadi di kelas XI IPA di MAN 1 PATI, berdasarkan hasil observasi dan wawancara dengan salah satu guru kimia menunjukkan bahwa pembelajaran kimia masih mengutamakan aspek kognitif saja sebagai indikator keberhasilan belajar. Di samping itu, guru lebih aktif sebagai pemberi ilmu dari pada siswa yang hanya mendengarkan penjelasan dari guru saja. Keaktifan guru tidak diimbangi dengan aktifnya siswa akibatnya siswa hanya mengetahui tentang konsep-konsep kimia tanpa berpikir tentang bagaimana cara menemukan konsep kimia tersebut. Apabila kegiatan belajar mengajar terus menerus dibiarkan seperti yang terjadi di kelas XI IPA MAN 1 PATI tersebut, maka akan memunculkan siswa yang berpikir "instan" karena mereka hanya menerima konsep kimia yang sudah jadi dan cenderung menghafalnya sehingga akan cepat lupa (Strawitz dan Malone 1987; Coil, et.al., 2010; Basu-Dutt, et.al., 2010).

Oleh karena itu, KPS perlu sekali dilakukan di MAN 1 PATI karena berdasar banyak penelitian, yang melaporkan bahwa KPS mampu mempromosikan perkembangan kognitif dan memberikan efek jangka panjang terhadap pencapaian pembelajaran (Preece dan Brotherton, 1997); memberi pemahaman bahwa sains (kimia) bukan hanya dianggap sebagai produk saja. Tetapi sains merupakan suatu proses. Bila hal ini dilakukan, maka menimbulkan ketertarikan siswa pada sains dan mereka tidak takut lagi (Riley, 1979). Jika siswa terlibat efektif dalam KPS, akan menampakkan pandangan bahwa pengetahuan bukan semata-mata teori (Wheeler, 2000; Ajaja, 2007). Bahkan mampu meningkatkan kecakapan proses dan pengetahuan sains siswa (Hodson, 1990, Chebii, et.al., 2012; ). KPS juga mendukung tercapainya pembelajaran bermakna karena mengintegrasikan aspek kognitif, afektif dan psikomotorik (Ebenezer, 1992; Bretz, 2001; Bretz, et.al., 2016). Di samping itu, KPS memungkinkan sekali dikembangkan lebih 
lanjut untuk mengetahui bagaimana pemahaman siswa sebenarnya melalui pelatihan berargumentasi secara ilmiah (Coopeer dan Oliver-Hoyo, 2016; Cigdemoglu, et.al., 2017). Bahkan keterampilan ini menurut Prayitno, et.al., (2017) dapat diintegrasikan ke dalam metode pembelajaran yang relevan seperti pembelajaran berbasis inkuiri dan kooperatif (seperti STAD). Kajian lainnya melaporkan bahwa Pembelajaran kooperatif (kolaboratif) mempromosikan kemampuan discovery learning (hipotesis, desain eksperimen, menyimpulkan) (Saab, et.al., 2005). Lebih lanjut, Hale-Hanes (2015) menyatakan bahwa KPS memungkinkan dilakukan untuk pengembangan model mental siswa. Melengkapi hasil penelitian yang telah dilakukan oleh Prayitno et.al (2017) dan HaleHanes (2015), ternyata KPS yang dipandu dengan guided inquiry menyebabkan pemahaman konsep, berpikir kritis, problem solving, dan kemampuan desain eksperimen lebih baik (Gaddis dan Schoffstall, 2007; Goodey dan Talgar, 2016; Weaver, et.al., 2016). Dengan demikian dapat diusulkan, pendekatan pembelajaran berbasis inkuiri yang dinamakan POGIL.

Banyak kajian tentang POGIL yang telah dilakukan, diantaranya siswa akan belajar lebih dalam tentang konsep karena waktu yang tersedia lebih lama daripada pembelajaran biasa (Conway, 2014). Soltis, et.al. (2015) mengungkapkan bahwa POGIL mampu meningkatkan keterampilan berpikir tingkat tinggi siswa dan meningkatkan hasil belajar (Hein, 2012). Lebih dari itu, siswa akan terlatih memiliki soft skills seperti kerja secara kooperatif dalam tim, konsep yang dipelajarinya akan lebih mudah dikuasai (Hunnicutt, et.al., 2015), kepemimpinan dalam penyelesaian masalah, memiliki keterampilan proses transfer (transferable process skills) yaitu kemampuan bekerja dengan gagasan kompleks, mengetahui sumber data yang valid, dan mampu menyimpulkan berdasar fakta atau bukti-bukti (Canelas, et.al., 2017). Keunggulan lainnya dengan POGIL mampu meningkatkan ketertarikan terhadap lingkungan belajar. Walaupun retensi dan self-eficacy tidak tampak (Chase, et.al., 2013), keberhasilan pendekatan ini dapat diperbaiki dengan peningkatan kualitas interaksi antar siswa (sesama anggota kelompok) dan siswa (anggota kelompok) dengan guru. Peranan utama dalam peningkatan kualitas interaksi ini adalah keterampilan guru dalam bertanya. Semakin baik keterampilan guru dalam bertanya, maka semakin membantu mampu menemukan konsep kimia yang sedang dipelajarinya dengan benar (Oliveira, 2010; Gillies, et.al., 2014; Treagust, 2007; Woods-Mc Conney et.al., 2016 ). Penelitian lainnya melaporkan bahwa POGIL memungkinkan sekali tercipta lingkungan belajar yang interaktif, konstruktif dan aktif (Farrell et.al., 1999). Lingkungan belajar yang demikian akan membantu siswa dalam pencapaian belajarnya (Chi, 2009; Chi dan Wylie, 2014). Namun, terdapat catatan dari Renken dan Nunez (2010) dalam pelaksanaan keterampilan inkuiri pada kegiatan praktikum bahwa perlu diperhatikan proses kognitif lainnya bila dijumpai dalam proses pembelajaran terdapat ketidaksesuaian antara teori dan fakta eksperimen.

Berdasar uraian masalah dan solusi yang ditawarkan di atas, artikel ini bertujuan mendeskripsikan kualitas KPS siswa kelas XI IPA MAN 1 PATI pada praktikum asam basa dan larutan penyangga melalui pendekatan POGIL.

\section{METODE PENELITIAN}

Metode penelitian yang digunakan Mixed Methods dengan data kualitatif ditempelkan dalam desain eksperimen, artinya data kualitatif sebagai pendukung desain eksperimen (Creswell \& Plano Clark, 2011). Sampel dalam penelitian ini yaitu siswa kelas XI IPA-1 MAN 1 PATI yang berjumlah 32 siswa. Adapun teknik pengambilan sampel dalam penelitian ini menggunakan teknik purposive sampling yaitu mengambil sampel pada kelas yang tersedia berdasarkan pertimbangan kemampuan siswa berbedabeda dari segi afektif, kognitif, dan psikomotorik sehingga representatif. 
KPS yang diteliti termasuk KPS dasar, meliputi mengamati perubahan warna dan perubahan $\mathrm{pH}$ pada berbagai macam larutan), mengklasifikasikan sifat larutan, menggunakan alat dan bahan (pipet tetes dan cara menuang larutan), mengukur volume larutan dan nilai $\mathrm{pH}$, interpretasi data (penulisan data pengamatan dan kesimpulan sementara), dan mengkomunikasikan (mendiskusikan hasil praktikum, pembacaan data hasil percobaan, penjelasan hasil percobaan, dan pembuatan laporan (Brotherton dan Preece, 1996; Preece dan Brotherton, 1997; Veal et.al., 2009; Gürses et. al., 2015). Ketujuh KPS ini dikaji lebih dalam dengan tahapan sebagai berikut: Tahap persiapan, pembelajaran, dan analisis data. Tahap persiapan terdiri dari dilakukan analisis kurikulum yang berlaku di MAN I Pati, penyusunan LKS berorientasi POGIL, instrumen penelitian dan validasi (lembar observasi, pedoman wawancara, catatan lapangan). Tahap berikutnya adalah melakukan pembelajaran berorientasi POGIL, melakukan observasi dan wawancara. Tahap yang terakhir terdiri dari menganalisis data hasil observasi, wawancara, catatan lapangan. Tahapan utama pembelajaran berorientasi POGIL meliputi orientasi masalah sederhana asam basa dan larutan penyangga dalam konteks sehari-hari, penyelidikan menggunakan KPS yang dipandu dengan LKS, diskusi kelas dan penguatan konsep.

\section{HASIL DAN PEMBAHASAN}

Data hasil penelitian diperoleh dari hasil observasi, catatan lapangan, dan wawancara dari siswa yang bersangkutan. Hasil wawancara dan catatan lapangan yang merupakan data kualitatif memperkuat data kuantitatif (hasil observasi). Temuan penelitian yang diperoleh berupa hasil observasi pada keterampilan mengamati, mengklasifikasi, menggunakan alat dan bahan, mengukur, menginterpretasi data, mengkomunikasi, dan menyimpulkan. Temuan hasil dari catatan lapangan dan wawancara digunakan sebagai data pendukung untuk melengkapi data dari hasil observasi.
3.1. Hasil Observasi Keterampilan Proses Sains Siswa Berdasarkan Observasi

Observasi yang dilakukan adalah menganalisis aspek-aspek keterampilan proses sains siswa yang tampak pada saat kegiatan praktikum menggunakan pendekatan POGIL pada materi asam basa dan larutan penyangga. Hasil ini diperoleh melalui observasi yang dilakukan oleh peneliti dan tiga observer pada saat praktikum berlangsung, yaitu pada keterampilan mengamati, mengklasifikasi, mengukur, menggunakan alat dan bahan, interpretasi data, berkomunikasi, dan menyimpulkan. Observer berada di arah belakang kelas sehingga tidak menganggu proses kegiatan praktikum yang berlangsung. Observer sesekali mendekat terhadap kelompok yang sedang melakukan praktikum untuk mencatat hal-hal penting. Hasil observasi keterampilan proses sains siswa pada seluruh kegiatan praktikum disajikan dalam Tabel 1. Rerata KPS tiap aspek dihitung dari skor masing-masing peserta didik dari data hasil observasi setiap indikator aspek KPS. Kemudian mengkonversi skor rerata KPS tersebut menjadi data kualitatif (Widoyoko, 2009). 
Tabel 1. Persentase Skor Tiap Aspek dan Skor Rata-Rata Keterampilan Proses Sains Siswa pada Praktikum Asam Basa dan Larutan Penyangga Berdasarkan Observasi.

\begin{tabular}{|l|l|l|l|l|}
\hline $\begin{array}{c}\text { Aspek } \\
\text { Keterampilan } \\
\text { Proses Sains }\end{array}$ & $\begin{array}{c}\text { Asam Basa } \\
\text { (Persentase } \\
\text { dan Kategori) }\end{array}$ & $\begin{array}{c}\text { Larutan } \\
\text { Penyangga } \\
\text { (Persentase dan } \\
\text { Kategori) }\end{array}$ & $\begin{array}{c}\text { Rerata KPS } \\
\text { Tiap Aspek } \\
\text { (Persentase) }\end{array}$ & Kategori \\
\hline Mengamati & $83,80 \%$ (Baik) & $\begin{array}{l}88,25 \% \text { (Sangat } \\
\text { Baik) }\end{array}$ & $85,00 \%$ & Baik \\
\hline Mengklasifikasikan & $81,25 \%$ (Baik) & $64,75 \%$ (Cukup) & $77,12 \%$ & Baik \\
\hline $\begin{array}{l}\text { Menggunakan Alat } \\
\text { dan Bahan }\end{array}$ & $77,75 \%$ (Baik) & $83,50 \%$ (Baik) & $80,62 \%$ & Baik \\
\hline Mengukur & $48,75 \%$ (Kurang) & $61,25 \%$ (Cukup) & $55,00 \%$ & Kurang \\
\hline $\begin{array}{l}\text { Menginterpretasi } \\
\text { Data }\end{array}$ & $71,87 \%$ (Baik) & $60,12 \%$ (Cukup) & $66,00 \%$ & Cukup \\
\hline Mengkomunikasikan & $66,25 \%$ (Cukup) & $54,68 \%$ (Kurang) & $58,78 \%$ & Cukup \\
\hline Menyimpulkan & $\begin{array}{c}50,75 \% \\
\text { (Kurang) }\end{array}$ & $44,50 \%$ (Kurang) & $47,62 \%$ & Kurang \\
\hline Jumlah Keseluruhan KPS (Asam Basa dan Larutan Penyangga) & $67,34 \%$ & Cukup \\
\hline
\end{tabular}

\subsection{Hasil Wawancara Terhadap Siswa}

Wawancara terhadap siswa dilakukan dengan tujuan untuk mengetahui respon siswa terhadap pembelajaran praktikum yang diberikan dengan menggunakan pendekatan POGIL dan dampak dari penerapan belajar menggunakan pendekatan POGIL terhadap kualitas keterampilan proses sains siswa. Wawancara ini dilakukan terhadap 5 siswa yang dijadikan sebagai sampel yang dipilih berdasarkan kategori kemampuan akademik tinggi, sedang, dan rendah dari masingmasing kelompok. Berikut hasil wawancara yang diperoleh melalui tahapan transkrip, klasifikasi dan reduksi:

a. Pada aspek mengamati, diantaranya mengalami kesulitan membedakan perubahan warna pada indikator $\mathrm{pH}$ universal misalnya merah, merah tua dengan orange. Namun terdapat pula siswa yang tidak mengalami kesulitan.

b. Pada aspek mengklasifikasi asam, basa dan larutan penyangga sebelum dan setelah penambahan sedikit asam kuat, basa kuat serta pengenceran. Terdapat siswa yang tidak mengalami kesulitan dan terdapat pula yang mengalami kesulitan membedakan perubahan sedikit $\mathrm{pH}$ pada larutan penyangga. Bahkan, waktu melihat dan menyesuaikan dengan kelompok lain terdapat perbedaan hasilnya. c. Pada aspek menggunakan alat dan bahan, siswa tidak mengalami kesulitan dalam menggunakan pipet tetes karena sebelumnya telah mengamati video praktikum diantaranya teknik menggunakan pipet tetes yang benar.

d. Pada aspek mengukur, saat pengukuran $\mathrm{pH}$, siswa mengalami kesulitan dan bahkan merasa gagal karena diperoleh perbedaan hasil pengukuran dengan kelompok lainnya. Kesulitan pada aspek pengukuran $\mathrm{pH}$ ini lebih banyak daripada aspek lainnya.

e. Pada aspek menginterpretasi data, siswa masih mengalami kesulitan karena harus menjawab beberapa pertanyaan yang membantu mereka menguasai konsep yang sedang dipelajari dan data yang diperoleh tidak lengkap. Mereka masih belum mampu membedakan antara menuliskan data hasil percobaan dengan interpretasi data.

f. Pada aspek mengkomunikasikan, siswa mengalami kesulitan dalam menuliskan hasil praktikum kelompok karena belum terbiasa membuat laporan percobaan.

g. Pada aspek menyimpulkan, siswa belum mampu mengkaitkan antara tujuan praktikum dan pembahasan. Bahkan beberapa siswa tidak menyimpulkan hasil praktikum. 


\subsection{Hasil Catatan Lapangan}

Catatan lapangan yang dikumpulkan pada saat penelitian meliputi kegiatan praktikum asam basa dan larutan penyangga di laboratorium IPA dan kegiatan pembahasan laporan praktikum di kelas XI IPA-1. Catatan lapangan ini ditulis oleh ketiga observer termasuk peneliti. Lembar catatan lapangan berisi data-data di luar data observasi. Data catatan lapangan ini (tabel 2) dijadikan data pendukung dalam penelitian yang dilakukan. Pada Tabel 1, terlihat bahwa pada aspek mengamati, kategori baik diperoleh skor paling tinggi (85\%) diantara aspek KPS lainnya. Hal ini didukung pada catatan lapangan, siswa terlihat antusias dalam mengamati dan menuliskannya pada tabel hasil pengamatan. Pada aspek menggunakan alat dan bahan termasuk kategori baik $(80,62 \%)$. Hal ini terbukti hasil catatan lapangan bahwa banyak siswa yang mampu menggunakan alat dan bahan dengan baik (pipet tetes, cara memindahkan larutan). Skor terendah terletak pada aspek menyimpulkan (47,62\%). Hal ini diperkuat dari catatan lapangan bahwa banyak siswa yang menuliskan kesimpulan dengan tidak lengkap. Bahkan dijumpai beberapa siswa tidak menyimpulkan hasil praktikum.

Tabel 2.Hasil Catatan Lapangan

\begin{tabular}{|c|c|}
\hline Aspek KPS & Temuan \\
\hline Mengamati & $\begin{array}{l}\text { - Siswa antusias dalam mengamati gejala-gejala yang yang terjadi pada } \\
\text { proses praktikum. } \\
\text { - Apa yang diamati siswa dituliskan semua pada tabel hasil pengamatan pada } \\
\text { LKPD. } \\
\text { - Beberapa siswa terlihat hanya diam saja dan dalam mengisi data } \\
\text { pengamatan hanya mencontoh teman sekelompoknya. } \\
\text { - Beberapa siswa hanya menulis hasil pengamatan sebagian saja (tidak } \\
\text { lengkap). }\end{array}$ \\
\hline Mengklasifikasi & $\begin{array}{l}\text { - Siswa dapat mengklasifikasikan sifat larutan asam basa dengan baik, tetapi } \\
\text { pada bagian percobaan } 2 \text { (penentuan sifat larutan asam basa saat ditetesi } \\
\text { dengan larutan indikator asam basa) masih banyak siswa yang belum bisa } \\
\text { mengklasifikasikan sifat larutan. Terlihat pada tabel data hasil pengamatan } \\
\text { masih banyak yang salah. } \\
\text { - Pada larutan penyangga, siswa dapat mengklasifikasikan sifat larutan } \\
\text { dengan cukup baik, meskipun ada beberapa siswa yang masih belum } \\
\text { lengkap dalam mengklasifikasikan, terlihat pada tabel hasil pengamatan } \\
\text { masih ada yang kosong pada kolom sifat larutan. }\end{array}$ \\
\hline $\begin{array}{l}\text { Menggunakan Alat } \\
\text { \& Bahan }\end{array}$ & $\begin{array}{l}\text { - Siswa sudah bisa menggunakan pipet tetes dengan benar. Tetapi beberapa } \\
\text { siswa masih ada yang salah dalam menggunakannya, yaitu pada saat } \\
\text { meneteskan larutan yang sudah diambil menggunakan pipet tetes dengan } \\
\text { ujung pipet tersebut masuk kebagian dalam larutan yang akan ditetesi. } \\
\text { - Siswa dapat menuangkan larutan dari gelas ukur ke dalam gelas kimia atau } \\
\text { dari gelas kimia ke dalam gelas kimia yang lain dengan baik. Beberapa siswa } \\
\text { ada yang menuangkan larutan dengan cara yang salah yaitu gelas ukur } \\
\text { tidak menempel pada dinding gelas kimia dan tidak dituangkan secara } \\
\text { perlahan. Terlihat ada yang menumpahkan larutan karena kurang kehati- } \\
\text { hatiannya. } \\
\text { Pada praktikum larutan penyangga, siswa dapat menggunakan alat dan } \\
\text { bahan dengan lebih baik lagi karena sudah belajar dari praktikum yang } \\
\text { pertama (praktikum asam basa), siswa lebih memahami cara menggunakan } \\
\text { alat dan bahan dengan benar meskipun beberapa siswa masih ada yang } \\
\text { salah dalam menggunakan alat dan bahan tetapi tidak seperti pada saat } \\
\text { melakukan praktikum asam basa. }\end{array}$ \\
\hline
\end{tabular}




\begin{tabular}{|c|c|}
\hline Aspek KPS & Temuan \\
\hline Mengukur & $\begin{array}{l}\text { - Tidak semua siswa dapat membaca pengukuran volume larutan dengan } \\
\text { benar, terlihat beberapa siswa membaca skala pengukuran volume larutan } \\
\text { dengan cara yang salah yaitu dengan mengangkat gelas ukur yang berisi } \\
\text { larutan saat membaca volumenya dan menggunakan meniscus atas. } \\
\text { - Rata-rata siswa membaca hasil pengukuran pH indikator universal dengan } \\
\text { cara yang salah yaitu dengan membandingkan perubahan warna yang } \\
\text { terjadi pada kertas indikator universal pada kode warna indikator universal } \\
\text { pada saat kertas indikator universal masih dalam keadaan basah. Inilah yang } \\
\text { menyebabkan kesalahan dalam penentuan nilai pH. } \\
\text { - Pada praktikum larutan penyangga, kemampuan siswa dalam mengukur } \\
\text { terlihat lebih baik dari praktikum asam basa karena sudah belajar (bertanya } \\
\text { dan diberi arahan) dari praktikum yang sebelumnya yaitu praktikum asam } \\
\text { basa, siswa lebih memahami cara mengukur dengan benar meskipun } \\
\text { beberapa siswa masih ada yang salah dalam mengukur tetapi tidak seperti } \\
\text { pada saat melakukan praktikum asam basa. }\end{array}$ \\
\hline $\begin{array}{l}\text { Menginterpretasi } \\
\text { Data }\end{array}$ & $\begin{array}{l}\text { - Siswa dalam menuliskan dan melengkapi data hasil pengamatan masih ada } \\
\text { yang salah meskipun beberapa terisi semua. Pengisian datanya pun masih } \\
\text { ada yang belum lengkap terutama pada percobaan } 2 \text { pada praktikum asam } \\
\text { basa, begitu juga pada praktikum larutan penyangga masih banyak yang } \\
\text { belum lengkap pengisian datanya pada bagian penentuan sifat larutan. } \\
\text { Mereka merasa kesulitan dalam interpretasi data ini, karena menuliskan hasil } \\
\text { pengamatan tergantung pada hasil praktikum yang sudah dilaksanakan. Jika } \\
\text { hasilnya praktikumnya salah, maka dalam pengisian data pun juga akan } \\
\text { salah. } \\
\text { - Pada praktikum asam basa pada bagian menarik kesimpulan sementara, } \\
\text { siswa dapat menarik kesimpulan dengan baik, terlihat banyak yang benar } \\
\text { dalam menarik kesimpulan yang dituliskan pada LKPD. } \\
\text { - Pada praktikum larutan penyangga, beberapa siswa kurang lengkap dalam } \\
\text { menarik kesimpulan sementara. } \\
\text { Terlihat juga beberapa siswa tidak menarik kesimpulan sementara dari hasil } \\
\text { praktikum yang telah dilaksanakan. } \\
\text { Pada praktikum larutan penyangga, kemampuan siswa dalam } \\
\text { menginterpretasi data tidak lebih baik dari praktikum asam basa, terlihat } \\
\text { pada saat menulis data pengamatan dari hasil praktikum yang telah } \\
\text { dilaksanakan mereka kebingungan terhadap hasil praktikum yang telah } \\
\text { didapat. Pada saat siswa bertanya dan diberi arahan, ternyata kebanyakan } \\
\text { siswa berpendapat bahwa praktikum larutan penyangga ini lebih sulit dari } \\
\text { praktikum asam basa, mereka kurang paham terhadap materi larutan } \\
\text { penyangga. }\end{array}$ \\
\hline Mengko & $\begin{array}{l}\text { - Siswa antusias dalam berdiskusi meskipun ada beberapa yang ramai dan } \\
\text { pasif. } \\
\text { - Siswa kurang bisa menerjemahkan data dari bentuk tabel ke dalam bentuk } \\
\text { tulisan dalam pembahasan laporan praktikum. Pembahasan pada } \\
\text { laporannya kurang lengkap sebab pengisian datanya pun kurang lengkap } \\
\text { yaitu pada praktikum asam basa percobaan } 2 \text { pada bagian penentuan sifat } \\
\text { larutan asam basa setelah ditetesi dengan larutan indikator asam basa. Pada } \\
\text { bagian percobaan tersebut, siswa kesulitan dalam menentukan perkiraan pH } \\
\text { larutan yang ditunjukkan pada data hasil pengamatan siswa tidak } \\
\text { menuliskan hasil perkiraan pH larutan. Pada praktikum larutan penyangga, } \\
\text { siswa kesulitan dalam mengukur pH larutan, ditunjukkan pada hasil } \\
\text { pengukuran pH larutan siswa banyak yang kurang tepat yang } \\
\text { mengakibatkan kesalahan dalam penentuan sifat larutan. }\end{array}$ \\
\hline
\end{tabular}




\begin{tabular}{|l|l|}
\hline Aspek KPS & \multicolumn{1}{|c|}{ Temuan } \\
\hline & $\begin{array}{l}\text { Pada saat menyampaikan hasil laporan praktikum, suasana kelas ramai } \\
\text { sehingga kegiatan penyampaian hasil laporan kurang maksimal. Siswa yang } \\
\text { lain kurang memperhatikan temannya yang maju ke depan. }\end{array}$ \\
& $\begin{array}{l}\text { Siswa dalam menulis laporan banyak yang kurang lengkap, seperti pada } \\
\text { tujuan percobaan tidak dituliskan, analisis data kurang lengkap, dan pada } \\
\text { pembahasan juga kurang lengkap. Terdapat beberapa siswa yang hanya } \\
\text { mencontoh pekerjaan teman sekelompoknya tanpa berpikir sendiri. Bahkan } \\
\text { beberapa siswa ada yang tidak membuat laporan pada praktikum asam } \\
\text { basa maupun larutan penyangga. }\end{array}$ \\
\hline Menyimpulkan & $\begin{array}{l}\text { Dalam pembuatan laporan, pada bagian kesimpulan rata-rata siswa tidak } \\
\text { menyimpulkan hasil percobaan dengan lengkap (hanya beberapa } \\
\text { percobaan saja). Bahkan beberapa siswa tidak menyimpulkan hasil } \\
\text { praktikum. }\end{array}$ \\
\hline
\end{tabular}

Berdasarkan kategori persentase skor ratarata dari ketujuh aspek KPS tersebut menunjukkan bahwa kemampuan siswa dalam mengukur dikategorikan kurang karena siswa kurang terampil dalam membaca hasil pengukuran $\mathrm{pH}$. Rata-rata siswa melakukan pengukuran $\mathrm{pH}$ dengan cara yang salah yaitu dengan membandingkan warna dari kertas $\mathrm{pH}$ dengan kode warna indikator universal secara langsung pada saat masih basah, yang seharusnya ditunggu setelah kering terlebih dahulu. Membaca nilai $\mathrm{pH}$ dibutuhkan ketelitian pada saat mencocokkan pada kode warna indikator universal dikarenakan warna-warnanya yang hampir sama, sehingga hal tersebut yang menyebabkan siswa kesulitan dalam membaca hasil pengukuran nilai $\mathrm{pH}$.

Kemampuan interpretasi data, tergolong cukup karena siswa terbantukan dengan pertanyaan-pertanyaan kritis dalam LKS yang menggiring pada penguasaan konsep (Farrell, 1999; Yang et.al., 2005; Paul dan Elder, 2008; Tofade et al., 2013). Walaupun demikian, kemampuan siswa dalam menyimpulkan dikategorikan kurang dikarenakan siswa belum mampu mengaitkan data yang diperoleh dari hasil praktikum dengan konsep materi yang benar. Hal ini dikarenakanketidaklengkapan data yang dihasilkan, tidak pahamnya materi, dan tidak mengetahui apa tujuan dan maksud melaksanakan praktikum. Dengan demikian terbukti bahwa siswa masih belum mampu menangkap maksud rangkaian pertanyaan kritis yang disusun mengikuti pendekatan
POGIL. Padahal rangkaian pertanyaan kritis tersebut membantu sekali siswa dalam menyimpulkan atau menemukan konsep. Hal ini serupa yang ditemukan oleh Zohar (2010) bahwa siswa tidak mampu membedakan antara hasil atau data percobaan dengan kesimpulan. Namun, jika siswa dibantu dengan rangkaian pertanyaan kritis guru, maka siswa mampu membedakan apa itu hasil percobaan dan kesimpulan.

KPS secara keseluruhan dapat dikatakan cukup baik $(67,34 \%)$, walaupun terdapat siswa yang kesulitan sehingga tidak menunjukkan KPS yang signifikan sebagaimana yang dilaporkan oleh Durmaz dan Mutlu (2016). Hal ini banyak faktor yang menjadi penyebabnya, antara lain ketidakbiasaan siswa mempelajari konsep kimia melalui praktikum berpendekatan POGIL yang merupakan pembelajaran yang berpusat pada siswa (Laius, et.al., 2015), kualitas interaksi siswa-siswa dan siswa-guru yang rendah (Woods-McConney et.al., 2016; Webb, 2009), keterampilan guru dalam mengajukan pertanyaan. Melalui pemberian informasi yang kontradiktif pada siswa mampu menstimulasi siswa dan terciptalah interaksi yang kondusif antara siswa-siswa dan siswaguru (Kirik dan Boz, 2012). Meskipun demikian, secara keseluruhan rata-rata keterampilan proses sains siswa pada kedua praktikum tersebut adalah cukup baik dengan persentase rata-rata $67,34 \%$.

Berdasarkan penelitian yang telah dilaksanakan, ada beberapa tahapan POGIL 
yang dilakukan dalam proses pembelajaran untuk mengidentifikasi keterampilan proses sains siswa diantaranya tahap eksplorasi, tahap formasi, dan tahap aplikasi. Dari tiga tahapan POGIL tersebut yang dapat memunculkan KPS siswa adalah pada tahap eksplorasi dan tahap formasi.

Pada tahap eksplorasi, peran siswa adalah melaksanakan percobaan sesuai dengan langkah-langkah yang terdapat pada petunjuk praktikum yang diberikan oleh guru, sedang peran guru adalah membimbing dan mengawasi jalannya praktikum, dan meminta siswa untuk mengajukan pertanyaan tentang hal yang belum dipahami pada saat melaksanakan praktikum. Pada tahap eksplorasi ini siswa melakukan percobaan dengan melakukan aktivitas seperti mengamati, mengklasifikasi, menggunakan alat dan bahan, mengukur, dan lain sebagainya untuk membangun pemahaman konsep dengan dibimbing oleh guru sehingga KPS siswa dapat dilatih dan pengetahuan yang didapatkan siswa diharapkan bukan dari hasil mengingat dan menghafal seperangkat fakta-fakta tetapi merupakan hasil dari menemukan sendiri (inkuirl).

Selain tahap eksplorasi, tahap formasi juga dapat memunculkan KPS siswa karena pada tahap iniguru sebagai fasilitator membantu siswa dalam menemukan konsep yang sedang dipelajari. Konsep tidak diberikan secara langsung, namun guru mendorong dan memacu siswa untuk dapat berpikir kritis dengan memberikan stimulus. Stimulus tersebut dapat berupa pertanyaan yang diberikan oleh guru atau pertanyaanpertanyaan yang terdapat pada LKS. Pertanyaan yang diberikan mengarahkan siswa untuk mengidentifikasi konsep dan pemahaman konsep yang dibangun, serta mengarahkan siswa untuk mengamati hal-hal yang dianggap menarik atau penting sehingga keterampilan, konsep atau prinsip yang menjadi sasaran dari pembelajaran tersebut dapat ditemukan.
Berikut contoh pertanyaan yang terdapat pada LKS pada praktikum asam basa percobaan 1:

1. Berdasarkan percobaan yang telah kalian lakukan, kelompokkan masing-masing larutan elektrolit berdasarkan hasil akhir perubahan warna kertas lakmus merah dan biru!

\begin{tabular}{|l|l|}
\hline $\begin{array}{l}\text { Perubahan warna kertas } \\
\text { lakmus merah dan biru }\end{array}$ & $\begin{array}{c}\text { Larutan } \\
\text { elektrolit }\end{array}$ \\
\hline Menjadi merah & \\
\hline Menjadi biru & \\
\hline
\end{tabular}

2. Kelompokkan larutan elektrolit yang merubah lakmus merah menjadi biru, lakmus merah tetap merah, lakmus biru menjadi merah, lakmus biru tetap biru !

\begin{tabular}{|l|c|}
\hline $\begin{array}{c}\text { Perubahan warna kertas } \\
\text { lakmus }\end{array}$ & $\begin{array}{c}\text { Larutan } \\
\text { elektrolit }\end{array}$ \\
\hline Merah menjadi biru & \\
\hline Merah tetap merah & \\
\hline Biru menjadi merah & \\
\hline Biru tetap biru & \\
\hline
\end{tabular}

3. Kelompokkan masing-masing larutan elektrolit yang merubah kertas lakmus dengan hasil akhir merah semua!

4. Kelompokkan masing-masing larutan elektrolit yang merubah kertas lakmus dengan hasil akhir biru semua!

5. Apakah larutan elektrolit A, B, C, D sama ?

6. Apakah larutan elektrolit A, B dengan larutan elektrolit $C, D$ sama ?

7. Apakah larutan elektrotit A dengan B, C dengan D sama?

8. Tentukan sifat dari masing-masing larutan elektrolit A, B, C, D !

\begin{tabular}{|l|l|}
\hline Larutan elektrolit & Sifat \\
\hline A & \\
\hline B & \\
\hline C & \\
\hline D & \\
\hline
\end{tabular}

Berdasarkan percobaan 1 yang telah kalian lakukan, maka dapat diketahui bahwa larutan asam adalah larutan yang dapat........................kertas lakmus biru menjadi.................... pan pada kertas lakmus merah..............merah. Sedangkan larutan basa adalah larutan yang dapat..........................kertas 
lakmus merah menjadi dan pada kertas lakmus biru biru.

Berdasarkan pertanyaan-pertanyaan tersebut, siswa dibimbing dan diarahkan untuk menjawab pertanyaan runtut satu persatu sehingga siswa dapat menemukan sendiri konsep asam basa yaitu siswa dapat menjelaskan sifat larutan asam basa menggunakan indikator kertas lakmus. Pada saat menjawab pertanyaan-pertanyaan tersebut siswa melakukan aktivitas-aktivitas seperti mengamati, mengklasifikasi, menginterpretasi data, dll sehingga keterampilan proses sains siswa dapat dilatih.

Jika dilihat dari LKS berdasarkan jawaban siswa tiap kelompok, pemahaman konsep siswa pada praktikum asam basa memperoleh persentase skor rata-rata $69,70 \%$ dengan kategori cukup, sedangkan pada praktikum larutan penyangga memperoleh persentase skor rata-rata $42,14 \%$ dengan kategori kurang. Persentase skor yang tidak memuaskan ini bahkan terjadi penurunan disebabkan kurangnya peran guru dalam mengelola kelompok, stimulus berupa pertanyaan yang menuntut siswa berpikir tingkat tinggi dan kritis (Webb, 2009). (Gambar 1).

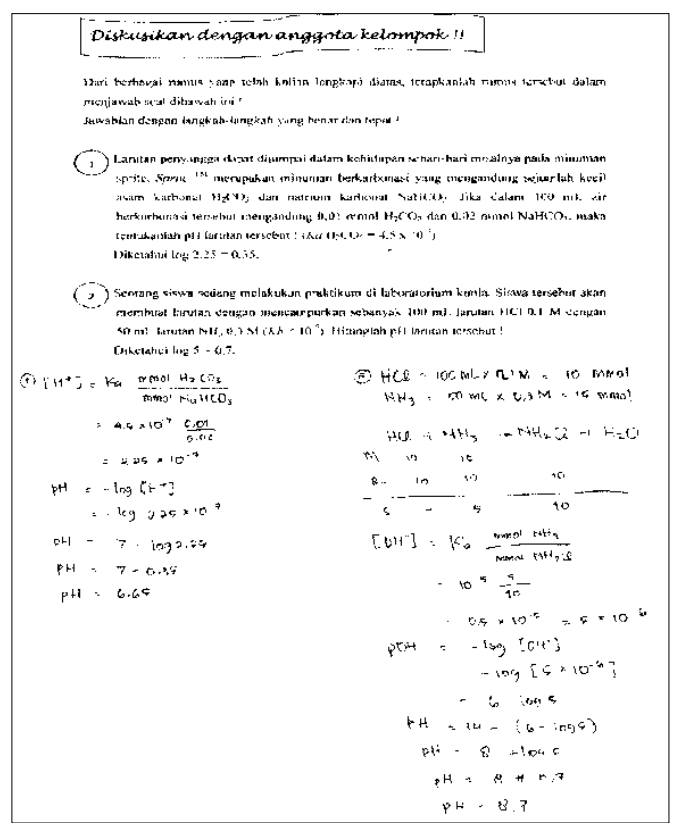

Gambar 1. Jawaban latihan soal di akhir lembar diskusi materi larutan penyangga
Meskipun demikian, KPS siswa cukup baik pada kedua praktikum yang telah dilaksanakan. Pembelajaran praktikum melalui pendekatan POGIL tersebut merupakan pembelajaran yang baru di MAN 1 PATI khususnya di kelas XI IPA. Hasilnya menunjukkan bahwa dengan pendekatan pembelajaran tersebut dapat menampakkan KPS siswa dengan cukup baik. Apabila pembelajaran dengan pendekatan POGIL diterapkan pada materi kimia selain asam basa dan larutan penyangga (dalam penelitian ini) yang memungkinkan dilakukan praktikum dan dilakukan pembiasaan sebelumnya, maka berpotensi dapat meningkatkan keterampilan proses sains siswa.

Hasil temuan penelitian ini juga memberikan implikasi selanjutnya bahwa jika siswa dibiasakan mempelajari konsep kimia dengan menggunakan KPS melalui POGIL akan mempermudah guru mengembangkan kemampuan siswa mendesain praktikum untuk pemecahan problem yang lebih kompleks (Goodey dan Talgar, 2016). Melalui penelitian ini juga dapat dikatakan bahwa perlunya penguatan terhadap relevansi materi asam basa dan larutan penyangga terhadap konteks kehidupan sehari-hari. Dengan demikian, akan memberikan keasadaran kepada siswa bahwa kimia itu relevan dengan kehidupan mereka dan hal ini akan membantu tercapainya pembelajaran kimia bermakna (Ebenezer, 1992). Selain itu juga secara tidak langsung akan memberikan motivasi siswa (Vaino dan Rannikmae, 2012). Sebaliknya jika penguatan terhadap konteks sehari-hari ini kurang optimal dalam pembelajaran dapat menurunkan motivasi dalam belajar, indikasinya dapat dilihat dari suasana kelas yang ramai ketika diskusi kelas berlangsung pada penelitian ini.

\section{KESIMPULAN}

Berdasarkan analisis terhadap hasil penelitian yang telah dilaksanakan di MAN 1 PATI dapat disimpulkan bahwa kualitas keterampilan proses sains siswa secara keseluruhan adalah cukup baik dengan persentase rata-rata 
$67,34 \%$. Profil keterampilan proses sains siswa pada setiap aspek keterampilan adalah sebagai berikut: aspek mengamati atau mengobservasi termasuk dalam kategori baik dengan persentase rata-rata $85,00 \%$; aspek mengklasifikasi termasuk dalam kategori baik dengan persentase rata-rata $77,12 \%$; aspek menggunakan alat dan bahan termasuk dalam kategori baik dengan persentase ratarata 80,62\%; aspek mengukur termasuk dalam kategori kurang dengan persentase rata-rata 55,00\%; aspek menginterpretasi data termasuk dalam kategori cukup dengan persentase rata-rata 66,00\%; aspek mengkomunikasikan termasuk dalam kategori cukup dengan persentase rata-rata $58,78 \%$; dan aspek menyimpulkan termasuk dalam kategori kurang dengan persentase rata-rata $47,62 \%$.

\section{UCAPAN TERIMA KASIH}

Terima kasih saya sampaikan kepada Drs. $\mathrm{H}$. Mashudi, M.Ag selaku Kepala MAN 1 Pati yang telah memberikan ijin riset. Tidak lupa saya sampaikan terima kasih pula kepada Umi Sa'idatul Mahmudah dan Linda Hesti Kumala yang telah membantu dalam pengumpulan data.

\section{DAFTAR PUSTAKA}

Avianti, R., dan Yonata, B., 2015, Keterampilan Proses Sains Siswa Melalui Penerapan model Pembelajaran Kooperatif Materi Asam Basa Kelas Xi Sman 8 Surabaya, UNESA Journal of Chemical Education, 4, 224-231.

Afiyanti, N. A., Cahyono, E., dan Soepardjo, 2014, keefektifan inkuiri terbimbing berorientasi green chemistry terhadap keterampilan proses sains, Jurnal Inovasi Pendidikan Kimia, 8, 1281 1288.

Ajaja, O.P., 2007, Teaching methods across diciplines, Agbor: All-Well Publishers.

Ash, D., 2000, The process skills of inquiry, chapter 7, Foundation: A Monograph for
Proffesionals in Science, Mathematics, and Technology Education, National Science Foundation

Basu-Dutt, S., Slappey, C., and Bartley, J. K., Making Chemistry Relevant to the Engineering Major, Journal of Chemical Education, 87, 1206-1212.

Bretz, S. L., Galloway, K. R., Orzel, J., and Gross, R., 2016, Faculty Goals, Inquiry, and Meaningful Learning in the Undergraduate Chemistry Laboratory, Chapter 6, ACS Symposium Series; American Chemical Society: Washington, DC.

Bretz, S. L., 2001, Novak's Theory of Education: Human Constructivism and Meaningful Learning, Journal of Chemical Education, 78, 1107-1115.

Brotherton, P. N., and Preece, P. F. W., 1996, Teaching Science Process Skills, International Journal of Science Education, 18, 65-74.

Canelas,D. A., Hill, D. L., and Novicki, A., 2017, Cooperative learning in organic chemistry increases student assessment of learning gains in key transferable skills, Chemistry Education Research and Practice, 18, 441-456.

Chase, A., Pakhira, D., and Stains, M., 2013, Implementing Process-Oriented, Guided-Inquiry Learning for the First Time: Adaptations and Short-Term Impacts on Students Attitude and Performance, Journal of Chemical Education, 90, 409-416.

Chebii, R., Wachanga, S., Kiboss, J., 2012, Effects of science process skills mastering learning Approach on students' Acquisition of selected chemistry practical skills in school, Creative Education, 3, 1291-1296.

Chi, M. T., H., 2009, Active-ConstructiveInteractive: A Conceptual Framework for Differentiating Learning Activities, Topics in Cognitive Science , 1, 73-105 
Chi, M. T., H., and Wylie, R., 2014, The ICAP Framework: Linking Cognitive Engagement to Active Learning Outcomes, Educational Psychologist, 4, 219-243.

Cigdemoglu, C., Arslan, H. O., and Cam, A., 2017, Argumentation to foster preservice science teachers' knowledge, competency, and attitude on the domains of chemical literacy of acids and bases, Chemistry Education Research and Practice, 18, 288-303.

Coil, D., Wenderoth, M. P., Cunningham, M., and Dirks, C., 2010, Teaching the Process of Science: Faculty Perceptions and an Effective Methodology, CBE-Life Science Education, 9, 524-535.

Conway, C. J., 2014, Effects of Guided Inquiry versus Lecture Instruction on Final Grade Distribution in a One-Semester Organic and Biochemistry Course, Journal of Chemical Education, 91, 480483.

Cooper A. K., and Oliver-Hoyo, M. T., 2016, Argument construction in understanding noncovalent interactions: A Comparation of two argumentation frameworks, Chemistry Education Research and Practice, 17, 1006-1018.

Coulson, E.H., 1972, Some Recent Developments in Chemistry Teaching in Schools, Chemical Society Reviews, 1, 495-521.

Creswell, J. W., \& Plano Clark, V. L. (2011). Designing and conducting mixed methods research (2nd ed.). Thousand Oaks, CA: Sage.

Das, R.S., 1985, science teaching in schools, New Delhi: Sterling Publishers.

Durmaz, H., and Mutlu, S., 2016, The effect of an instructional intervention on elementary students' science process skills, The Journal of Educational Research, 1-13.

Ebenezer, J. V., 1992, Making Chemistry Learning More Meaningful, Journal of Chemical Education, 78, 464-467.

Farrell, J. J., Moog, R. S., and Spencer, J. N., 1999, A Guided Inquiry General Chemistry Course, Journal of Chemical Education, 76, 570-574.

Fitriyani, R., Haryani, S., dan Susatyo, E. B., 2017, Pengaruh Model Inkuiri Terbimbing Terhadap Keterampilan Proses Sains Pada Materi Kelarutan dan Hasil Kali Kelarutan, Jurnal Inovasi Pendidikan Kimia, 11, 1957 - 1970.

Gaddis, B. A., and Schoffstall, A. M., 2007, Incorporating Guided-Inquiry Learning into the Organic Chemistry Laboratory, Journal of Chemical Education, 8, 848851.

Gillies, R. M., Nichols, K., Burgh, G., \& Haynes, M. (2014). Primary students' scientific reasoning and discourse during cooperative inquiry-based science activities. International Journal of Educational Research, 63, 127-140.

Goodey, N. M., and Talgar, C. P., 2016, Guided inquiry in a biochemistry laboratory course improves experimental design ability, Chemistry Education Research and Practice, 17, 1127-1144.

Gürses, A., Çetinkaya, S., Doğar, C., and Şahin, E., 2015, Determination Of Levels Of Use Of Basic Process Skills Of High School Students, Procedia-Social and Behavioral Sciences, 191, 644 - 650

Hale-Hanes, C., 2015, Promoting students development of models and scientific inquiry skills in acid-base chemistry: an important skill development in preparation for AP chemistry, Journal of Chemical education, 92, 1320-1324.

Hardiyanti, P. C., Wardani, S., dan Nurhayati, S., 2017, Keefektifan Model Problem Based Learning Untuk meningkatkan 
Keterampilan Proses Sains Siswa, Jurnal Inovasi Pendidikan Kimia, 11, 18621671.

Hein, S. M., 2012, Positive Impacts Using POGIL in Organic Chemistry, Journal of Chemical Education, 89, 800-804.

Hodson, D., 1990, a critical look at practical work in school science, School Science Review, 71, 33-40.

Hofstein, A., and Lunetta, V. N., 1982, The Role of the Laboratory in Science Teaching: Neglected Aspects of Research, Review of Educational Research, 52, 201-217.

Hofstein, A., and Lunetta, V. N., 2004, The laboaratory in science education: Foundations for the twenty-first century, Science Education, 88, 28-54.

Hofstein, A., 2004, The Laboratory in Chemistry Education: Thirty Years of Experience With Developments, Implementation, and Research, Chemistry Education Research and Practice, 5, 247-264.

Hunnicutt, S. S., Grushow, A., and Whitnell, R., 2015, Guided-Inquiry Experiments for Physical Chemistry: The POGIL-PCL Model, Journal of Chemical Education, 92, 262-268.

Kirik, O. T., and Boz Y., 2012, Cooperative learning instruction for conceptual change in the concepts of chemical kinetics, Chemistry Education Research and Practice, 13, 221-236.

Laius, A., Valdmann, A., \& Rannikmae, M. (2015). A Comparison of transferable skills development in Estonian school biology at gymnasium level. ProcediaSocial and Behavioral Sciences, 177, 320-324.

Oliveira, A. W. (2010). Improving teacher questioning in science inquiry discussions through professional development. Journal of Research in Science Teaching, 47(4), 422-453.

Prayitno, B.A., Corebima, D., susilo, H., Zubaidah, S., and Ramli, M., 2017, Closing the science process skills gap between students with high and low level academic achievment, Journal of Baltic Science Education, 16, 266-277.

Padilla, M.J., 1990, The science process skills, National association for research in science teaching, https://www.narst.org/publications/rese arch/skill.cfm (diakses juli 2017).

Paixão, M.F., and Cachapuz, A., 2000, Mass Conservation In Chemical Reactions: The Development of An Innovative Teaching Strategy Based On The History And Philosophy Of Science, Chemistry Education: Research and Practice In Europe, 1, 201-215.

Paul R, Elder L. 2008. Critical thinking: the art of Socratic questioning, part III. J Dev Educ. 31, 34-35.

Preece, P. F. W., and Brothertion, P. N., 1997, Teaching science process skills: longterm effects on science achievement, International Journal of Science education, 19, 895-901.

Rahmawati, R., Haryani, S., dan Kasmui, 2014, Penerapan Praktikum Berbasis Inkuiri Untuk Meningkatkan Keterampilan Proses Sains Siswa, Jurnal Inovasi Pendidikan Kimia, 8, 1390-1397.

Reid, N. And Shah, I., 2007, The role of laboratory work in university chemistry, Chemistry Education Research and Practice, 8, 172-185.

Renken, M. D., and Nunez, N., 2010, Evidence for Improved Conclusion Accuracy after Reading about Rather than Conducting a Belief-inconsistent Simple Physics Experiment, Applied Cognitive Psychology, 24, 792-811. 
Riley, J.P., 1979, The influence of Hands-on science process training on pre-service Teachers' acquisition of process skills and attitude. toward science and science teaching, Journal of Research in Science Teaching, 16, 373-384.

Saab, N., Joolingen, W. R., and Van HoutWolters, H. A. M., 2005, Communication in collaborative discovery learning, British Journal of Educational Psychology, 75, 603-621.

Soltis, R., Verlinden, N., Kruger, N., and Carroll, A., 2015, Process-Oriented Guided Inquiry Learning Strategy Enhances Students' Higher Level Thinking Skills in a Pharmaceutical Sciences Course, American Journal of Pharmaceutical Education, 79, 1-8.

Strawitz, B. M., and Malone, M. R., 1987, preservice teachers' acqcisition and retention of integrated science process skills: a comparison of teacher-directed and self-instructional strategies, Journal of Research in Science Teaching, 24, 5360.

Sukardi. 2015. Metodologi Penelitian Pendidikan Kompetensi dan Praktiknya. Cetakan ke-14. Jakarta: BumiAksara.

Tofade, T., Elsner, J., and Haines, S. T. 2013. Best Practice Strategies for Effective Use of Questions as a Teaching Tool. American Journal of Pharmaceutical Education. 77, 1-9.

Tomasevic, B., and Trivic, D., 2014, Creativity in teaching chemistry: how much support does the curriculum provide?, Chemistry Education Research and Practice, 15, 239-252.

Treagust, D. F. (2007). General instructional methods and strategies. In S. K. Abell \& N. G. Lederman (Eds.), Handbook of research on science education (pp. 373391). Aarhus: Lawrence Erlbaum Associates.
Tuckwell, W., 1865, Science-Teaching in Schools, Nature, 1, 18-20.

Vaino, K., Holbrook, J., and Rannikmae, M., 2012, Stimulating students' intrinsic motivation for learning chemistry through the use of context-based learning modules, Chemistry Education Research and Practice, 13, 410-419.

Veal, W. R., Taylor, D., and Rogers, A. L., 2009, Using Self-Reflection to Increase Science Process skills in the General Chemistry Laboratory, Journal of Chemical Education, 86, 393-398.

Wardani, S., Widodo, A. T., dan Priyani, N. E., 2009, Peningkatan Hasil Belajar Siswa Melalui Pendekatan Keterampilan Proses Sains Berorientasi ProblemBased Instruction, Jurnal Inovasi Pendidikan Kimia, 3, 391-399.

Weaver, M. G., Samoshin, A. V., Lewis, R. B., and Gainer, M. J., 2016, Developing Students' Critical Thinking, Problem Solving, and Analysis Skills in an Inquiry-Based Synthetic Organic Laboratory Course, Journal of Chemical Education, 93, 847-851.

Webb, N. M., 2009, The teacher's role in promoting collaborative dialogue in the classroom, British Journal of Educational Psychology, 79, 1-28.

Wheeler, G.F., 2000, Three faces of inquiry in J.M. Intress and E.H. van zel (eds), inquiring into inquiry learning and teaching in science, washington DC: American association for the Advancement of science.

Widoyoko, Eko Potro. 2009. Evaluasi Program Pembelajaran Panduan Praktis Bagi Pendidikan dan Calon Pendidik. Yogyakarta: Pustaka Belajar.

Woods-McConney, A., Wosnitza, M., and Sturrock, K. L., 2016, Inquiry and groups: student interactions in cooperative inquiry-based science, International 
Journal of Science Education, 38, 842860.

Yang Y. C, Newby T. J, Bill R. L. 2005. Using Socratic questioning to promote critical thinking skills through asynchronous discussion forums in distance learning environments. Am J Distance Educ. 19, 163-181.

Zohar, A., 2010, Result or conclusion? Students' differentiation between experimentalresults and conclusions, Journal of Biological Education, 32, 5359. 